\title{
The social myth and human domination of nature in Georg Sorel and Stanisław Brzozowski
}

\author{
Krystof Kasprzak ${ }^{1}$ (D)
}

Accepted: 9 March 2021 / Published online: 31 March 2021

(C) The Author(s) 2021

\begin{abstract}
In this article I aim to bring to the fore a problematic trait of Polish philosopher Stanisław Brzozowski's (1878-1911) thinking, which is his insistence on the metaphysical importance of human domination of nature through work, technology, and maximization of production. The focal point of the article is Brzozowski's interpretation of Georg Sorel, with an emphasis on Reflections on Violence and the concept of the social myth. I argue that Brzozowski considers the primary strength of the social myth to lie in its contribution to such domination, because its principal trait is to provide man with a sublime feeling of elevation above nature. Furthermore, this feeling becomes a motive force for struggle against nature. In conclusion, I suggest that the perspective of the sublime is a fruitful path for future critical encounters with Brzozowski's work. The first part of the article stresses the importance of the sublime in Reflections on Violence. Sorel uses this concept throughout his main work to describe the affective nature of the violence of the social myth, which coordinates the inclinations of the masses towards emancipation. The second part discusses how Brzozowski understands the social myth, law, and nationhood from the perspective of human domination of elemental nature.
\end{abstract}

Keywords Stanisław Brzozowski · Georg Sorel $\cdot$ Social myth · Sublimity · Nature · Polish socialism

Krystof Kasprzak

krystof.kasprzak@sh.se

1 The Centre for Studies in Practical Knowledge, School of Culture and Education, Södertörn University, Södertörns högskola, Alfred Nobels allé, 14189 Huddinge, Stockholm, Sweden 


\section{Introduction}

Stanisław Brzozowski (1878-1911) is the main Polish representative of what has become known as 'Western Marxism' through his development of a praxis-oriented philosophy, characterised by a resilient anti-Engelsianism. ${ }^{1}$ From 1906, Georg Sorel was one of the primary sources of inspiration for the development of Brzozowski's thinking because of his insistence on the affective nature of class struggle, in stark contrast to the prevailing Engelsian understanding of it as merely an effect of an automated historical process. Especially after reading Reflections on Violence, Brzozowski recognises Sorel as his closest ally among contemporary thinkers (Walicki 1989, 145). In a letter from January 1907, he writes:

When life overwhelms me I read Sorel and thank the subterranean Gods that I am a contemporary of this man. His Réflexions sur la violence express all that I have recently dreamt. For me, he and Bergson incarnate contemporary philosophy. (Brzozowski quoted from Ibid. 145)

Famously, the key subject of Reflections on Violence is the violent nature of the social myth. This theme inspires Brzozowski the most in his many-faceted reading and development of Sorel's philosophy. In what follows, I focus on one side of this development to bring to the fore a problematic trait of Brzozowski's thinking, which is his insistence on the metaphysical importance of human domination of nature through work, technology and the maximisation of production. I argue that he considers the primary strength of the social myth to lie in its contribution to such domination, because its principal trait is to provide humanity with a feeling of elevation above nature, which becomes a motive force for the struggle against nature. In other words, the social myth is sublime in Immanuel Kant's sense of the word. For an attentive reader of Reflections on Violence this is evident, as Sorel implements the concept of the sublime throughout the text when he describes the affectivity of the myth. However, it is not as apparent in Brzozowski since the notion of the sublime is absent in his discussions about myths. Still, the aesthetic of the sublime is a promising source for new critical encounters with Brzozowski's philosophy. I propose one such path for future research when I close this article with a reference to Hannah Arendt: the presence of the sublime in Brzozowski's philosophy might provide an insight into how he resonates with a general titanistic tendency in modern thought, which she describes as 'a rebellion against the very factuality of the human condition' because of its desire to ground human existence upon itself (Arendt 1970, 13).

The first part, 'The Sublimity of the Social Myth in Reflections on Violence', reveals the importance of the sublime in Sorel's main work. He employs this concept throughout Reflections on Violence when he describes the affective nature of

\footnotetext{
1 Andrzej Walicki's Stanistaw Brzozowski and the Polish Beginnings of "Western Marxism" is the most comprehensive introduction to Brzozowski's thinking for English readers (Walicki 1989). See also the chapter on Brzozowski in Leszek Kołakowski's Main Currents of Marxism: Its Origins, Growth, and Dissolution; 2. The Golden Age (Kołakowski 1981). One of Brzozowski's most important texts is called 'Anti-Engels' (Brzozowski 1990).
} 
the violence of the myth. There is a sublimity to how its motive forces coordinate the inclinations of the working class towards emancipation. Although Sorel is not completely clear on this point, the Kantian influence is emphasised, specifically regarding the sublimity of the moral law. In the second part, 'The Social Myth in Brzozowski', I primarily turn to the essays 'Jerzy Sorel' (1907) ('Georg Sorel'), 'Powstanie prawa' (1907) ('Rise of the Law'), 'Bergson i Sorel' (1910) (Bergson and Sorel), and 'Mity i legendy' (1910) ('Myths and Legends'). I examine how Brzozowski understands the social myth in relation to the human domination of nature, legislation and nationhood. In conclusion, I suggest that Brzozowski's thinking can be interpreted as being heavily influenced by the sublime feeling of human elevation above nature.

\section{The sublimity of the social myth in reflections on violence}

\section{The of social myth as an intensification inclinations}

The social myth is, for Sorel, a motive force for transformative action in the present (Sorel 2004, 28). This definition is directed against all forms of utopianism. Unlike utopian ideas, myths are not descriptions of things but expressions of a will to act:

A utopia is, on the contrary, an intellectual product; it is the work of theorists who, after observing and discussing the facts, seek to establish a model to which they can compare existing societies in order to estimate the amount of good and evil they contain. (Ibid. $28 \mathrm{f}$.). ${ }^{2}$

Utopianism provides an image of the future whose possibility is modelled on the current state-therefore, utopians become excellent statesmen (Ibid. 28 f.). In contrast, the myth opens the present through human action. It is inseparable from the heroic deeds of a social group, which arouse the present to become eventful and creative. Furthermore, social myths are future oriented, but in a different manner than utopianism. Sorel writes:

we are unable to act without leaving the present, without considering the future, which seems forever condemned to escape our reason. Experience shows that the framing of the future in some indeterminate time may, when it is done in a certain way, be very effective and have few inconveniences; this happens when it is a question of myths, in which are found all the strongest inclinations of a people, of a party or of a class, inclinations which recur to the mind with the insistence of instincts in all the circumstances of life, and which give an aspect of complete reality to the hopes of immediate action upon which the reform of the will is founded. We know that these social myths in no way prevent a man from knowing how to profit from the observations he

\footnotetext{
${ }^{2}$ Unless stated otherwise, all translations are my own.
} 
makes in the course of his life and form no obstacle to the pursuit of his normal occupations. (Ibid. 115)

The future-oriented nature of the social myth concerns present inclinations. They are processes that Sorel compares to the insistence of instincts 'in all the circumstances of life', which make possible what he designates 'the reform of the will' in the quotation above. Myths structure inclinations into an image. Sorel contends that people who struggle in social movements 'always picture their coming action in the form of images of battle in which their cause is certain to triumph' (Ibid. 20). But again, unlike utopias, social myths are not explicit depictions of possible states of the future. When Sorel writes that they frame the future in some indeterminate time, one must be attentive to the specific meaning of these concepts. In fact, it is easier to comprehend how myths are opposed to utopias if they are interpreted from the perspective of Bergson's understanding of indeterminacy and time (Bergson is, of course, Sorel's prime philosophical inspiration): for the image of the future to generate something new and not merely permutate a present state, it has to imply the indeterminacy of freedom (Bergson 1946, 122).

Gilles Deleuze underlines that the indeterminacy of freedom in Bergson regards the actualisation of virtualities, not the realisation of possibilities. Unlike the static character of the possible, indeterminacy is 'the image's way of extending itself in movement' (Deleuze 1988, 67). The indeterminate image evolves through creative differentiation because 'in order to be actualized, the virtual cannot proceed by elimination or limitation, but must create its own lines of actualization in positive acts' (Ibid. 97). This indicates that myths do not become politically powerful images through the limitation of pre-conceived possibilities. Such a strategy belongs to utopianism, as a process of realisation by way of resemblance: the utopian image resembles the possible it is supposed to realise, and it is limited beforehand because not all possibilities can be realised. In contrast, the virtual image of the social myth is actualised through 'difference or divergence and [...] creation' (Ibid. 97).

In Sorel's words, the indeterminate time of social myths entails that they 'are not astrological almanacs; it is even possible that nothing which they contain will come to pass'. The inclinations that myths coordinate are instead 'merely' motive forces 'of acting on the present', like the passing thoughts that appear in everyday life, which we know may be unfulfilled but 'that does not prevent us from continuing to make resolutions' (Sorel 2004, $116 \mathrm{f}, 119$ ). Myths powerfully affect the fusion of such motive forces-lines of actualisation-that belong to the life of particular social groups. They coordinate the constantly self-differentiating movements of these groups by continuously maximising the intensity of their emancipatory tendencies (Ibid. 113 fn. 4, 118). The mythical intensification of inclinations into emancipatory motive forces is violent, and the meaning of this violence is the overarching theme of Reflections on Violence.

\section{The sublimity of violence}

According to Sorel, we must 'ask ourselves what will result from the introduction of violence into the relations of the proletariat with society' (Ibid. 43). It is 
apparent that he considers proletarian violence to disrupt social relations through an intensification of the feeling of freedom, which actualises the indeterminacy of time in direct contrast to the homogeneity of the status quo. In this sense, proletarian violence opens the present towards the future. It is creatively inventive when it acts upon the present. However, the more precise question Sorel attempts to answer is: Under what condition does proletarian violence promote a genuine feeling of freedom that can become the main character trait of the working class? At least in Reflections on Violence, the answer clearly concerns the aesthetic affectivity of the sublime, as the overwhelming feeling of 'our freedom' through struggle (Ibid. $26 \mathrm{f}$.):

the notion of the proletarian general strike [...] awakens in the depth of the soul a sentiment of the sublime proportionate to the conditions of a gigantic struggle; it forces the desire to satisfy jealousy by malice into the background; it brings to the fore the pride of free men and thus protects the worker from the charlatanism of ambitious leaders eager for pleasures. (Ibid. 159)

The sublime feeling that accompanies the social myth-in this case the myth about the general strike-shelters the workers from moral decay. It is critical to acknowledge that Sorel is in many ways a moralist, just like his precursor Proudhon (Jennings 1985, 154). He considers the decadent nature of capitalism to belong to a general moral decline of Western culture since classic antiquity. Therefore, the paramount concern for Sorel's ethico-political thinking is that 'Sublimity has vanished from the Ethics' (Sorel 2004, 209). Aesthetic elevation is necessary for the moral liberation of the working class. This should be interpreted in Kantian terms. Although Sorel primarily remains a student of Bergson, as regards the unique contribution of the social myth to a moral awakening, he is - in a broad sense-a follower of Kant (especially in Reflections on Violence). This is underlined by Sorel's marked emphasis on the ethical significance of the notion of the sacred in Émile Durkheim:

Professor Durkheim said recently, at the Société Française de Philosophie (11 February 1906), that it would be impossible to suppress the sacred in ethics and that what characterized the sacred was its incommensurability with other human values; he recognized that his sociological researches led him to conclusions very near to those of Kant; he asserted that utilitarian morality had misunderstood the problem of duty and obligation. I do not want to discuss these arguments here; I simply cite them to show to what point the character of the sublime impresses itself on authors who, by the nature of their work, would seem to be the least inclined to accept it. (Ibid. 205)

The concept of the social myth undoubtedly appears to be coupled with Kant's aesthetics of the sublime. In Sorel's eyes, it encourages a cultural rebirth of the 'proudly pessimistic conception of life' of the tragedians:

The pre-Socratic Greeks had [...] a sense of the limits to which human action could aspire, a sense of the obstacles that were placed in the way of success, a sense, simply, of the suffering involved in all human activity and of the possible misfortunes that could, and probably would, befall them. This, Sorel 
argued, was the basis of a true doctrine of pessimism - which was not that of a disappointed optimist. (Jennings 1985, 22)

The workers are not morally elevated by an 'illusion of progress' (to paraphrase the title of Sorel's book) through faith in a fetishised notion of history as an automated process (Sorel 1969). Instead, they are carried by a sublime respect for their dignity as producers of the world, which raises them above any reassurance about historic victory or defeat. ${ }^{3}$ They precipitate an 'ethic of the producers', based 'on the feelings developed by the struggles of the workers against their masters' (Sorel 2004, 33). Since the future ethic Sorel has in mind is based on the distinct feelings of the workers about the sublimity of their creative endeavours, it is conditioned by an aesthetic that powerfully moves them to morally surpass the ruling un-productive class: 'the sublime is dead in the bourgeoisie and it is doomed to possess no ethic in the future' (Ibid. 229). Unlike the notable absence of the sublime in the bourgeoisie, Sorel considers it to be most heroically expressed by the 'poorest people' specifically because of their fundamental lack of concern for utilitarian calculations (Ibid. 210-211 f.):

during revolutions the poorest people have often given the finest examples of heroism; they explain it by assuming that these obscure heroes were true children of nature. I explain it by saying that, these men being engaged in a war which was bound to end in either their triumph or enslavement, the sentiment of sublimity was bound to be engendered by the conditions of the struggle.

(Ibid. 210)

As I have argued, Sorel should be interpreted in Kantian terms when he writes that the heroism of the 'poorest people' does not depend on them being the 'true children of nature': 'the poor' are awakened to valiant struggle through the sublime feeling of reason's ability to give itself a law, not through sensibility (to which all self-interest and any utilitarian calculations properly belong). They are touched by 'the sublimity of our nature' and a sense of moral dignity and absolute responsibility when elevated above the 'pathologically affected nature' of humankind (Kant 2015, 72-73, 75). For Sorel, revolutionary aspirations are in themselves aesthetically sublime, and they pave the way for morally determined action (Sorel 2004, 209 f.). They distance the workers from their sensuous existence, which Sorel describes as frivolous:

\footnotetext{
3 Of course, an 'illusion of progress' is essential to Kant, but in the form of a regulative idea of reasona regulative idea of progress is very different from the idea about progress as a law of history (which is a transcendental illusion proper, because history is a totality that can only be the object for reflective and not determinate judgments). To what extent the social myth can be interpreted as a regulative idea has to be treated elsewhere, not least because it would have to extensively confront the Bergsonian metaphysics that underlie Sorel's thought. It seems, however, that Laclau and Mouffe open the possibility for an interpretation that unites the Bergsonian and Kantian traits in Sorel when they describe the social myth as a 'regulating principle, which allows the proletariat to think the mélange of social relations as organized around a clear line of demarcation; the category of totality, eliminated as an objective description of reality, is reintroduced as a mythical element establishing the unity of the worker's consciousness' (Laclau and Mouffe 2001, 40).
} 
The idea of the general strike, engendered by the practice of violent strikes, entails the conception of an irrevocable overthrow. There is something terrifying in this - which will appear more and more terrifying as violence takes a greater place in the mind of the proletarians. But, in undertaking a serious, formidable and sublime work, the socialists raise themselves above our frivolous society and make themselves worthy of pointing out new roads to the world. (Ibid. 281)

\section{The social myth in Brzozowski}

\section{The coordinative function of the social myth and human domination of nature}

Brzozowski's philosophical interpretation of the social myth is intimately tied to his metaphysics of work, which defines work as the fundamental ground-creating activity of man, revealed as such by way of the extensive experience of nihilism in modernity-when modern humanity is confronted with the nothingness of the world, it is thrown back upon itself as the ground-creating worker that only finds proper footing in the world via his own making. ${ }^{4}$ Brzozowski deems social myths to be decisive for this productivity, since it principally concerns forms of life that come about "through "transgression of the limits of actuality", through movements (ruchy) that bring the subject outside of itself and [...] its current lifeform' (Kasprzak 2020). ${ }^{5}$

In 'Myths and Legends', Brzozowski emphasises the coordinative activity of the social myth, which Sorel perceives as its essential function. Just like in Sorel, this must be interpreted against the background of Bergson's philosophy. For Brzozowski, social myths coordinate the continuous flow of life, i.e. the heterogeneity of time where there is no fatherland (ojczyzna), no proletariat, no art (Brzozowski

\footnotetext{
${ }^{4}$ Kopij argues for a proximity between Brzozowski's thinking and Jünger's. She even considers the former to be a precursor in spirit to the latter (and to Oswald Spengler) when she stresses the metaphysical dimension of work in both thinkers. For them, work denotes 'the spiritual and bodily activity of man' in the sense that it incorporates all other forms of life (Kopij 2006, 147-148 f.). In Brzozowski as well as in Jünger, technology is the means for this incorporation, with ontological consequences: 'in the world where a return to nature has become impossible, [technique] is the only alternative to Being' (Ibid. 155).

5 The main shortcoming of Kasprzak 2020 seems to be the absence of a distinction between labour and work in his interpretation of the irrationality of praca in Brzozowski. Such a distinction would be possible to make through Arendt: Brzozowski is primarily interested in praca as work-which refers to 'objective aims and ends', i.e. durability — and not labour-which refers to 'subjective needs and ends', i.e. 'the devouring processes of life' (Arendt 1998, 144). Moreover, Walicki consistently uses labour when he refers to praca in Brzozowski (Walicki 1989). However, the blurring of concepts stems from Brzozowski himself. His philosophy belongs to what Arendt describes as a general tendency 'in the labor philosophy of the modern age' to obscure all sorts of distinctions: between labour and work, making and thinking, fabrication and action (Ibid. 117, 305-306). This is a result of the dominance of homo faber and animal laborans, and a simultaneous confusion of the two. The 'biologization' of this confusion-also present in Brzozowski-is for Arendt most clearly expressed in Sorel's unification of Marx and Bergson where worldliness and action cease to be the main concern, replaced by an interest in 'life and life's fertility' (Ibid. 313).
} 
1997, 86). Is is stressed here because Brzozowski's argument is directed against traditional ontology. In time, beings do not exist as static substances that remain identical to themselves. Instead, identity is a necessary illusion created through the word, which he defines analogically to how he describes the social myth. It is 'the organ for coordination of life processes' (Ibid. 86). This coordination proceeds through hypostasis; the word delineates the identity of something in a way that simultaneously turns this identity into a ground for human life, by which he means a ground for work. ${ }^{6}$

Since the word forms something that lasts at least for some time in the flow of time, its mythical articulation is itself a work that institutes further grounds for work. This is how the word or speech (mowa) is the 'medium for social coordination'. However, since language is inherited, the meaning of a word typically tends to appear as if it came from a transcendent sphere, which conceals the obscure ground of time that makes any established meaning precarious (Ibid. 86, 92). This concealing 'as if' remains the conservative element of speech in relation to myths. Brzozowski constantly struggles against it, because it subtly transforms the creativity of myths into 'theological dogmas', by which he means any form of naturalisation of human life (theism, naturalism, materialism, etc.) (Ibid, 86). ${ }^{7}$ When that occurs, what is reified is endowed with a life of its own beyond human activity, and it takes part in what Brzozowski calls 'fetishism of concepts' (Ibid. 87, fn. 1). ${ }^{8}$

As a 'concrete coordination of human coexistence', the word is already a hypostasis, which is an activity of reification (Ibid. 87). When such a reification becomes fetishised, it affects the posture in relation to the world of the social group it concerns:

\footnotetext{
${ }^{6}$ Brzozowski seems to use hypostasis according to its metaphysical meaning; it signifies an underlying substance that is a substratum or a ground. However, he considers such grounds to be created through human work, to which the mythical articulation of the word belongs: something becomes a ground for human life through hypostasis.

7 For Brzozowski, the strength of Sorel is that he does not think in categories of what is already created, but 'in the moments of creativity itself'. He is not a 'theologian' in Brzozowski's sense (Brzozowski 1990, 273). Cf. Orska 2019, 141.

8 Walicki writes the following on the topic of reification in Brzozowski: 'Bergsonism harmonized with some tendencies in Brzozowski's historicism, especially with his critique of alienated and reified forms of life. Bergson, however, did not believe in liberating people from the reified structures of consciousness; in his view reification was inherent in language and thus inevitably bound up with "being human". Brzozowski agreed with this but wanted to reduce reification to the necessary minimum by unceasing struggle words and transforming them into "independent beings", (Walicki 1989, 152). I do not fully agree with Walicki's interpretation, because I think that Brzozowski's concept of fetishism has to be taken into account. As I have argued above, reification through hypostasis is not yet fetishisation. Brzozowski's point is not to keep the former to a 'minimum', but to reify in line with the requirements of productive work, which is itself a process of work. The main problem is for Brzozowski not reification, but fetishisation. In his understanding, reification is a necessary creation of grounds for life that can be evaluated as such. Therefore, reification is always open to a transformation. However, when what is reified is also fetishised, it is closed off from every possible critique and treated as an inherited necessity. That is, unlike reification, fetishisation is inherently dogmatic (in the Kantian sense of making transcendent claims). What leads Walicki astray as regards this specific subject is that he understands Brzozowski to be a precursor to Lukács, specifically his 'theory of reification' (Ibid. 155). As Walicki extensively shows, there are many proximities between Brzozowski and Lukács, but the reifying function of hypostasis in the former is not the same as reification in the latter (Brzozowski does not have the commodification of human labour/work in mind when he discusses hypostasis).
} 
the life form of this group obtains an illusory life of its own and is taken for granted as the way life should be lived. The mythical coordination of human inclinations becomes static (Ibid. 92). This means that the social myth loses its emancipatory power when it is regarded as a given system of values which is an object of cognition, and not as a living creation of values whose worth should be appraised from the perspective of how desirable they are as motive forces for action. ${ }^{9}$

What is said above can be summarised in the following way: the social myth is for Brzozowski a necessary coordination of the inclinations of the life of a social group through the reifying nature of the word, which can further be subjected to fetishisation. While fetishisation attracts mechanical forms of action, reification produces an image of thought (obraz myślowy) that encourages creativity through the transgression of forms of life that have ceased to positively transform themselves. ${ }^{10}$ In Bergson's spirit, the latter can be likened to laughable automatons and the former to vital-creatively evolving-bodies (Bergson, 1924). Unlike fetishised mythswhich Sorel describes as utopias and which Brzozowski calls legends-the social myth is a creative way to address what should be done in a situation when one's inclinations say that something must be done. According to Brzozowski, this means that it introduces a heroic element to thought without separating thinking from living, which he considers to be equivalent to working, in its turn equivalent to acting. Thinking is no longer like Hegel's owl of Minerva, which takes flight when the shades of night are gathering, but a movement of self-transgression in the present (Ibid. 114). ${ }^{11}$ Brzozowski describes this transgressive movement of myths in Bergsonian terms when he writes that they are the autocreation of the future through the deep self: 'The deep self has to have a plan for action' (Ibid. 115). As I have insisted on both in my reading of Sorel and of Brzozowski, this 'plan' is not a determined path but rather an image of thought provided by the social myth, which should be interpreted as a sketch and not as a finished drawing (unlike utopias or legends). Without such a sketch, the deep self 'would have to think about itself in terms of a past, ready-made reality and in this way constantly lose itself' (Walicki 1989, 152).

Nonetheless, even the openness of a sketch is limited, since it is propelled by a beginning that provides it with a direction. Expressed with the distinction from Deleuze discussed in the previous section on Sorel: the eventful actualisations of a beginning are different from the realisation of the possibilities of what has already begun, since the former are characterised by 'divergence and of creation' and the latter by 'elimination or limitation' (Deleuze 1988, 97). From the perspective of the activity of drawing, the more complete it becomes, the more the virtual lines of actualisation lessen for the sake of possible realisations that firmly take hold of what is to be done: an image is formed through the activity of drawing, which

\footnotetext{
${ }^{9}$ Brzozowski does develop a philosophy of values, deeply inspired by Kant, that I cannot treat here. A key text would be 'Monistyczne pojmowanie dziejów i filozofia krytyczna' ('Monistic Comprehension of History and Critical Philosophy') (Brzozowski 1973).

${ }^{10}$ In Walicki's words, 'Thought deprived of the mythical element cannot help to change the world' (Walicki 1989, 148).

11 For a discussion about the difference between the heroic element of the myth and the conservative traits of legends, see Chrostowska $(2005,536)$.
} 
increasingly becomes the model for all lines that are drawn. The beginning ceases to be the creative evolution of a form. Instead, it becomes an intended image by a-by now-determinate subject, obstinate in its endeavours to meticulously complete the picture. This is the case in Brzozowski, whose interpretation of the social myth is marked by a fundamental limit—by an absolute criterion for elimination-through his fierce insistence on one image as the primary motive force for action, which is that of human domination of nature.

Man's domination of nature is a very-at times extremely-pronounced aspect of Brzozowski's understanding of self-transgression: it transpires primarily through the conquering of elemental nature, outside and within man. ${ }^{12}$ Somewhat astonishingly, he deems such conquering to be the core strength of the social myth. He even considers it to be the main point of the general strike (Ibid. 113). However, one has to fathom that Brzozowski primarily understands the proletariat as the 'productive avantgarde of humanity' that 'increases the technical might of man', not as a class that struggles for social emancipation. The proletariat possesses a metaphysical significance for him. It keeps and extends the "human "footing in being" through the maximisation of production. Walicki argues that this reveals an insensitivity in Brzozowski regarding the potential dangers of technology: that a world dominated by technology, through the cult of work and the glorification of man as a producer, can indeed become more alienating for man than elemental nature (Walicki 1974, 200-201, 209). ${ }^{13}$

Brzozowski's disregard for the dangers of technology rests on the Promethean character of his thinking. Walicki writes that he even approached Sorel's ethics of the producers as a 'remedy against alienation' (Walicki 1989, 323). The myth of Prometheus - the Titan who stole fire from the Gods-recurs throughout his philosophy as an iconic symbol for a struggling and abandoned humanity, which lacks any other grounds for its existence than those created through its own work. In the spirit of this thought, Brzozowski believes that (what he considers to be) the social myth of class conflict in Marx is titanistic, and he describes Sorel (who, in his eyes, is a more profound thinker than Marx) as Promethean because of his affirmation of absolute creativity (Brzozowski 1990, 275, 279). For Brzozowski, 'Eurocentrism and the Promethean ethos characteristic of the West were not a flaw but a great merit of classical Marxism' (Walicki 1989, 328).

Owing to the prevalence of the myth of Prometheus in Brzozowski, Brzozowski scholar Andrzej Mencwel proposes that his image of the whole of humanity can be pictured as a titan that carries the earth (Mencwel 2014, 656). Here, just like Sorel, the Polish philosopher should primarily be read as an ardent follower of Kant and not of Bergson, which is underscored by Walicki's observation:

\footnotetext{
12 Chrostowska recognises this aspect of Brzozowski's thinking when she writes that his 'idea of a creative human conquest of nature and his tendency to absolutize history are indeed transcendental' (Chrostowska 2005, 528). She also describes him as having an 'obsession with creativity/productivity' (Ibid. 537).

13 Walicki also stresses the importance of Nietzsche for Brzozowski's interpretation of Sorel and his view of 'the working class as the heroic vanguard of humankind in the struggle for autocreation' (Walicki 1989, 146).
} 
Sorel's view of Marxism, at the time of his closest involvement, agreed with Brzozowski's interpretation on many important points, among them the view of Marxism as solving Kantian problems by explaining the dependence of human knowledge on the forms of production, a rejection of economic determinism and the theory of 'automatic progress', and the vindication of the ethical foundations of Marxism while accompanied by a stressing of the priority of those values which enhance human productivity. (Walicki 1989, 145)

Brzozowski agrees with Sorel that Marxism solves Kantian problems, not to leave critical philosophy behind but to make it more concrete. The Kantian abyss between the realm of will and the realm of sensibility and the imperative of the former to determine the latter is retained. However, while Kant attempts to bridge this abyss aesthetically and teleologically in Critique of Judgement, Sorel and Brzozowski consider it to be overcome through technology and the enhancement of human productivity. This might seem far removed from Kant, except for the fact that at the base of their solution to the Kantian problem lies an affective dimension, which is that of the sublime. I have already argued for its importance in my interpretation of Sorel's concept of the social myth. The following quotation from Brzozowski's 'Kant. W stulecie śmierći' (1904) ('Kant. On the Occasion of the Hundredth Anniversary of his Death') indicates that the sublime is also crucial for him. With an unmistakable reference to it, he stresses that critical philosophy is emancipatory precisely because it strives to ground man upon himself:

Humanity was supposed to find in itself the ground for both the order that rules the starry heavens above its head, and the moral imperative that determines the direction of its actions. (Brzozowski 1973, 256)

\section{The social myth and nationhood}

Sorel poses the following question in Reflections on Violence:

'Why is it that in certain countries acts of violence can group themselves around the general strike and produce a socialist ideology capable of inspiring sublimity; and why in others do they seem not to have that power?' Here, national traditions play a great part; the examination of this problem would perhaps throw a strong light on the genesis of ideas; but we will not deal with it here. (Sorel 2004, $213 \mathrm{f}$.)

This passage accurately describes the acute problem that guides Brzozowski's interest in the social myth in the historical context of partitioned Poland; how are viable national myths formed? In his reading, Sorel properly recognises that if a people aspire to assert itself as an independent nation, its historical consciousness must be embossed by the idea (the social myth) about human domination of nature at the 
highest level of technological development (Brzozowski 1997, 96, 106). ${ }^{14}$ Nature is the fertile 'terrain' for human freedom comprehended as work, which transforms it into an 'obedient ground' through technology (Brzozowski 1990, 157). Only what effectively takes part in such a consciousness counts as real, because the idea about nature as man's obedient ground is the absolute measure for the viability of all other ideas. ${ }^{15}$ It determines if they are merely chimeras, i.e. by-products of divergent lines that ought to be erased from the initial sketch. Furthermore, the concept of nature as an obedient ground should serve as the consistent basis for human law, since it is the condition for the cultural uniformity (jednolitość) of national life (Brzozowski 1997, 102-103 f.). However, the converse is also the case for Brzozowski: domination of nature is only effective if it is grounded in nationhood. A people-or a class-that lacks national uniformity cannot achieve a social environment for such supremacy, which is why workers' movements must be national. The nation amply provides 'a stable and hard ground under our feet' (Ibid. 251). In contrast, 'A human without a nation is a spirit without content, indifferent, dangerous and harmful' (Ibid. 250). ${ }^{16}$ For Brzozowski, just as for Sorel, there are as many socialisms as there are nations (Wyka 1972, 107):

To presume the workers' movement can be independent from the fates of national life, is to claim it does not matter what range of motives and means it will have at its disposal. [---] To renounce national being means to renounce the possibility to have an influence on the shaping of human reality; it means annihilating one's own spirit, because spirit only lives and acts through the nation. (Brzozowski 1990, 250)

The secondary literature on Brzozowski has justly observed that the precise meaning of his concept of nationhood is vague, e.g. how the nation differs from the state and clan-like communities (Sowa 1976, 106 f., 113 f.). Nevertheless, it is obvious that he considers nationhood to be a specific form of community (wspólnota) that summons its members to make subjective efforts. Polish philosopher Ewa Sowa argues that he comprehends it as an autonomous whole which creates independent wholes (culture) through the determination of a will that shapes history (Ibid. 110).

\footnotetext{
14 Brzozowski finds it problematic that Marx did not realise the intricate relation between technology and moral development. Proudhon had a far better understanding of this (Brzozowski 1997, 106, f.n. 4).

15 The idea of nature as man's obedient ground can be interpreted as the dominant regulative idea in Brzozowski. Walicki notes that it is possible to approach Brzozowski's aesthetics and ethics as guided by such an idea (Walicki 1989, 238). However, I believe he underplays that it is indeed normative in Brzozowski. Regulative ideas in Kant are normative, because they are derived from the moral law (if they belong to practical reason). But they are not determinate, because they do not apply to objects of intuition.

16 In Hegemony and Socialist Strategy, Ernesto Laclau and Chantal Mouffe point out that it is not necessary for the 'politically or mythically reconstituted subject [...] to be a class subject' in Sorel. The reason lies in his anti-economism, whose consequence 'is that the very identity of social agents becomes indeterminate and that every "mythical" fixation of it depends upon a struggle'. Laclau and Mouffe argue that this indeterminacy is a strength of Sorel's political philosophy. However, it also opened the possibility for nationalist interpretations of his thoughts that 'contributed to the rise of fascism' (Laclau and Mouffe 2001, 41).
} 
Without fully developing her thoughts, she suggests that the underlying question for Brzozowski concerns how nations can last as such totalities of historically creative endeavours (Ibid. 116).

The answer to Sowa's question lies in Brzozowski's understanding of the nation as a social myth. As a community that inspires its members to earnestly engage in subjective efforts, it is a social myth: Poland is a myth, which has to become active and morally strong in opposition to the occupiers through a seamless incorporation of the myth of a working class that conquers elemental nature (Brzozowski, 1997, 115). This interpretation agrees with a precise observation that Walicki makes when he identifies a semantic difference between fatherland and nation in Brzozowski:

Fatherland and nation often seem synonymous terms for him, but closer examination reveals an interesting semantic difference. The term fatherland, as Brzozowski uses it, applies to three spheres of social life: (1) family structure, (2) material production, and (3) statehood with its military organization. The term nation, on the other hand, denotes the subjective side of the fatherland, namely a certain continuity of the collective will, reproducing itself in history, an independent 'stream of life' objectifying itself in a certain language. In other words, fatherland is the external shape of 'the deepest reality', while nation is its inner kernel. (Walicki 1989, $164 \mathrm{f}$.)

Brzozowski states: 'Society exists as an emotional fact, as a various felt blind compulsion [mus] to coordinate our actions' (Brzozowski 1997, 87). He deems the nation to be the most powerful social form for such coordination, to the considerable extent that he sometimes grants it a metaphysical status (Walicki 1989, 165 f.). According to Brzozowski, Sorel realises (in agreement with Ernest Renan) that the fatherland contains a 'mystical, mythological core', an irreducible quid that efficiently generates an irrational bond between those who belong to it: it is an 'enormous obscure I' experienced as an 'emotional necessity'. This 'obscure ground' of the fatherland is the creative source for the inventiveness of its culture, inseparable from the 'ability to acquire new experiences' that encourage new 'decisions, aspirations, actions': from the depths of the fatherland, the nation prepares 'plan[s], plane[s] for action' aimed at technologically inventive mastery of the elements (Brzozowski 1997, 88-90, 99). ${ }^{17}$

As Walicki emphasises above, the nation constitutes the obscure kingdom of motives that orient the will of a people. It is the 'subjective side of the fatherland'

\footnotetext{
17 In 'Bergson and Sorel' (1910) Brzozowski writes that 'the whole of Sorel's philosophy' is concentrated in the notion of the fatherland (ojczyzna), which is an accumulation of past life, from which a people is able to extract educational means for the sake of maximising production (Brzozowski 1990, 265). 'Things exist that are older and deeper than nations, but man only knows himself through the nation, because there are no nationless, international organs of spiritual life.' (Ibid. 269). Therefore, nationhood is 'the only and the most profound ground in being' (Ibid. $267 \mathrm{f}$.). As Walicki stresses, this has to be interpreted in Bergsonian terms. Unlike, for example, utopian projections of finished images of the past, a nation's past is a 'living tradition' that is creatively future oriented because it belongs to the duration of the deep self (Walicki 1989, 152). Walicki quotes the well-known sentence from Creative Evolution: 'Duration is the continuous progress of the past which gnaws into the future and which swells as it advances' (Bergson quoted from Ibid.).
} 
that allows a people to uniquely inhabit the world, through spontaneous and instinctive coordination of its inclinations. In further agreement with Sorel, Brzozowski stresses that for a nation to become socialist, such plans must be freely accepted (przyjmowanym) through laws that its workers establish themselves. The law ought to be identical to their will. Only then can the proletariat lead a dignified life, elevated above nature through a feeling of respect and absolute responsibility for its work (Ibid. 107, 112; Brzozowski 1973, 519).

Sorel's insistence that the working class needs to rise above the frivolousness of its social being shines through as a fundamental theme in Brzozowski. It is crucial for the latter that Sorel's philosophy endorses the character traits of 'courage, energy, and a sense of honour', 'linked to a view of workers as a disciplined, law-creating force' (Walicki 1989, 146). However, Brzozowski does not simply agree with Sorel that emancipation must be achieved at the highest level of production, that the workers must 'increase their productivity or at least [...] maintain the level of productivity achieved under capitalism' (Ibid. 209). There is a distinct emphasis in Brzozowski that the moral elevation of the working class transpires through technological domination of nature, directed by laws that obey the demand for maximal productivity. This leitmotif of Brzozowski's thinking is already present in his early texts on Sorel. In 'Georg Sorel', he stresses that the proletariat must carefully develop a juridical consciousness (świadomość prawna) - that it 'forges the law itself' - in line with the demand for maximal productivity (Brzozowski 1973, 519). Here lies the significance of the syndicates: 'they are the ironworks of socialist juridical consciousness' and they do 'not recognize any law beyond the purposeful organization of productive activity' (Ibid. 520). A similar theme is developed in 'Rise of Law', where Brzozowski asserts that the law should never be derived from facts. This means that he distances himself from two forms of legal positivism: legal rationalism on the one hand, and the conservative-historical view of legislation on the other. Both relate to 'laws as facts, as opposed to ideal norms', which ought to be '[imposed] on the unmanageable reality'. For Brzozowski, the true essence of legislation resides in 'a conscious struggle for new laws' (Walicki 1989, 208). In direct contrast, to relate to laws as facts fetishises them and inadvertently promotes obedience and fear-but not respect (Brzozowski 1990, 153). Without respect, which in a Kantian sense concerns the autonomy of will, legislation merely demonstrates strength (siła) while 'Socialism is not only a question about strength; but the rise, the birth of law' (Ibid. 154). Brzozowski argues that this characterises the struggle of the working class:

The political struggle of the working class is a struggle against what appears to be law, but is merely strength. In its inner essence the worker's movement forges [wykuwa] the law. (Ibid. 154)

We owe this profound insight to Sorel, writes Brzozowski, which means that Sorel manages to salvage what is most crucial in the social struggles of the working class: he reveals how legislation belongs to 'the essence of life itself' (Ibid. 154-155). This statement is directed against the prevailing vulgar Marxist interpretation of the law as a part of the superstructure, which treats it as a mere product of 
the relations of production without any direct effect on these fundamental relations of its own:

The juridical consciousness of the working masses is the form of consciousness that today remains in utmost proximity to the sphere of human productivity, and therefore it exerts the most profound influence on social change. A victory that does not rest on the consciousness of the masses can never be ultimate or certain. Most importantly, it cannot be the emancipation of these masses. That is only possible when the masses experience the changes as their own work, when they consider the social relations implemented to be their own law. Socialism is primarily a struggle for the law of work since it is the struggle for the independence of the working class. (Ibid. 155)

When Brzozowski writes 'independence of the working class' he alludes to 'work that rules itself', which can only come about through workers' self-education. Referring to Proudhon, he states: 'democracy is demopedia' (Ibid. 155). ${ }^{18}$ Socialism is not realised through an ordinary struggle for political power (o wtadze). Instead, it is the creation of a new type of human being - the conscious worker-to whose consciousness belongs the idea that 'the creation of law can be criticized by every citizen'. Everyone should have the ability to question the law and take part in its rise, for it not to be a mere mechanical implementation of a rule that is alien to life. Nevertheless, the imperative for the self-education Brzozowski has in mind remains the maximisation of production through domination of nature. A people's judicial critique is solely valid if it contributes to establish an identity between maximal production, legislation, collective will, and technological development (Brzozowski 1990, 156). If this is fulfilled, work becomes the 'source and the aim of law', and history is made by human will (Ibid. 161).

The morally self-disciplining aspect of the social myth is realised through legislation. When Brzozowski writes 'We still live under the law, not in the law', he has the social myth in mind. The social myth is the law experienced from within as an effective self-determination - and its organisational effectiveness is measured through the ability to dominate nature and maximise production-in contrast to legislation to which one is externally subjected (Brzozowski 1990, 154). One lives precariously under the law through an imposed will, while living in the law is to form life according to one's own will. ${ }^{19}$

Brzozowski's ethical interpretation of socialism is closely tied to the forming of an-in the broadly Kantian sense discussed-autonomous will, which is emphasised by the fact that he calls the social myth an idea (Brzozowski 1990, 285). The overshadowing concern as to his interest in the social myth is the possibility of selfdetermination through laws one gives oneself. Such laws are a manifestation of the 'deepest human reality', which is autocreation (Brzozowski 1997, 177). Socialism

\footnotetext{
18 Just as with Sorel, Brzozowski is inspired by the rigid puritanical values endorsed by Proudhon (Walicki 1989, 147).

19 Walicki notes the Fichtean influence in Brzozowski's notion of the law, as the dominance of the I over the non-I (Walicki 1974, 210).
} 
is for him, as it is for Sorel, a moral imperative (Baczko 1974, 160). It is a grand vision about a humanity that becomes a sovereign and self-sufficient autarkoumen (Mencwel 2011, 85). This necessitates a moral atmosphere that enables a tragic struggle with metaphysical proportions: everything human ought to be the result of autonomous and disciplined work, because it is the fundamental condition for an ethic of absolute responsibility (Baczko 1974, 167; Walicki 1989, 162). The moral atmosphere unites the will that wants work and the activity of work, so that they may become an autonomous expression of the creative spirit of a national community. Brzozowski can be said to develop the 'ethic of the producers' and the sublime 'ethic of the future' that Sorel demanded, in consonance with the overwhelming feeling of the (dynamically) sublime:

Might is a power which is superior to great hindrances. It is termed dominion if it is also superior to the resistance of that which itself possesses might.

Nature considered in an aesthetic judgment as might that has no dominion over us, is dynamically sublime. (Kant 2007, 90)

The sublime feeling that carries both Sorel's and Brzozowski's thoughts about human supremacy over nature epitomises a philosophical problem that ought to be addressed as such. However, it is more apparent in Brzozowski because of the profoundness and consistency of his thinking regarding this matter. It is the consistency of a titanism that characterises modern thought as a whole, which I merely hinted at in this article when I mentioned his Promethean interpretation of Marx and Sorel. I believe that Arendt captures the core of this titanism well when she notes that.

all notions of man creating himself have in common a rebellion against the very factuality of the human condition - nothing is more obvious than that man, whether as member of the species or as an individual, does not owe his existence to himself (Arendt 1970, 13). ${ }^{20}$

Funding Open access funding provided by Södertörn University. The submitted article is part of the postdoctoral project "The Relation between Work and Political Emancipation from a Central and Eastern European Perspective: Autocreation, Work and Suffering in Stanisław Brzozowski”, funded by The Foundation for Baltic and East European Studies.

\section{Declarations}

Conflict of interest On behalf of all authors, the corresponding author states that there is no conflict of interest.

\footnotetext{
20 This is a problem that concerns homo faber: 'The animal laborans, which with its body and the help of tame animals nourishes life, may be the lord and master of all living creatures, but he still remains the servant of nature and the earth; only homo faber conducts himself as lord and master of the whole earth. Since his productivity was seen in the image of a Creator-God, so that where God creates ex nihilo, man creates out of given substance, human productivity was by definition bound to result in a Promethean revolt because it could erect a man-made world only after destroying part of God-created nature' (Arendt 1998, 139). Compare fn. 5 above.
} 
Availability of data and material Not applicable.

Code availability Not applicable.

Ethical statements The manuscript in part or in full has not been submitted or published anywhere. The manuscript will not be submitted elsewhere until the editorial process is completed.

Open Access This article is licensed under a Creative Commons Attribution 4.0 International License, which permits use, sharing, adaptation, distribution and reproduction in any medium or format, as long as you give appropriate credit to the original author(s) and the source, provide a link to the Creative Commons licence, and indicate if changes were made. The images or other third party material in this article are included in the article's Creative Commons licence, unless indicated otherwise in a credit line to the material. If material is not included in the article's Creative Commons licence and your intended use is not permitted by statutory regulation or exceeds the permitted use, you will need to obtain permission directly from the copyright holder. To view a copy of this licence, visit http://creativecommons.org/licen ses/by/4.0/.

\section{References}

Arendt, H. (1970). On violence. New York: Harcourt, Brace \& World.

Arendt, H. (1998). The human condition. . Chicago: The University of Chicago Press.

Baczko, B. (1974), Absolut moralny i faktyczność instnienia. In Walicki A./Zimand R. (Ed.), Wokót myśli Stanistawa Brzozowskiego. Kraków: Wydawnictwo literackie.

Bergson, H. (1924), Laughter: An Essay on the Meaning of the Comic, authorized translation by Brereton C. and Rothwell F. Temple of Earth Publishing, https://www.templeofearth.com/books/laughter.pdf. Accessed 9 November 2020.

Bergson, H. (1946). The creative mind (Mabelle L. Andison, Trans.). New York: The Philosophical Library inc.

Brzozowski, S. (1973). Kultura i życie. . Warszawa: Państwowy Instytut Wydawniczy.

Brzozowski, S. (1990). Idee: wstęp do filozofii dojrzałości dziejowej. . Kraków: Wydawn. Literackie.

Brzozowski, S. (1997). Legenda Młodej Polski: studia o strukturze duszy kulturalnej. . Kraków: Wydawnictwo Literackie.

Chrostowska, S. D. (2005), Stanisław Brzozowski., Philosopher of History, Myth, and Will", New Literary History (Vol. 36, No. 4).

Deleuze, G. (1988), Bergsonism (Barbara Habberiam and Hugh Tomlinson, Trans.), New York: Zone Books. Jennings, J. R. (1985). Georges Sorel. . London: Macmillan.

Kant, I. (2007), Critique of Judgment (James Creed Meredith, Trans.). Oxford: Oxford University Press.

Kant, I. (2015), Critique of Practical Reason (Mary Gregor, Trans.). Cambridge: Cambridge University Press

Kasprzak, K. (2020). The irrationality of labour in Stanisław Brzozowski's philosophy of 'labour.' Studies in East European Thought. https://doi.org/10.1007/s11212-020-09373-3.

Kołakowski, L. (1981). Main currents of marxism: Its origins, growth, and dissolution; 2. The golden age. . Oxford: Oxford U. P.

Kopij, M. (2006), Antizipationen des Arbeiters. Nietzsche-Brzozowski-Jünger. In (Ed.) Kopij, M./ Kunicki, W., Nietzsche und Schopenhauer. Rezeptionsphänomene der Wendezeiten, Leipzig: Leipziger Universitätsverlag.

Laclau, E., \& Mouffe, C. (2001). Hegemony and Socialist Strategy. . Verso.

Mencwel, A. (2011), Filozofia dojrzałości dziejowej. In Szroeder-Dowjat, K., Brzozowski. (Ed.), Przewodnik Krytyki Politycznej. Warsaw: Wydawnictwo Krytyki Politycznej.

Mencwel, A. (2014). Stanistaw Brzozowski: postawa krytyczna: wiek XX. . Wydawnictwo Krytyki Politycznej.

Orska, J. (2019). Brzozowski and the Italians. In J. Herlth \& E. M. Świderski (Eds.), Stanisław Brzozowski and the migration of ideas. London: Transcript Verlag.

Sorel, G. (1969). The Illusions of Progress (Johan and Charlotte Stanley, Trans.), Berkley: University of California Press.

Sorel, G. (2004). Reflections on Violence (Thomas Ernest Hulme, Trans. Edited by Jeremy Jennings), Cambridge: Cambridge University Press. 
Sowa, E. (1976). Pojęcie pracy w filozofii Stanistawa Brzozowskiego. . Wydaw. Literackie.

Walicki, A. (1974), "Brzozowski i rosyjscy 'neomarksisci", in (Ed.) Walicki A./Zimand R., Wokót myśli Stanistawa Brzozowskiego. Kraków: Wydawnictwo literackie.

Walicki, A. (1989). Stanistaw Brzozowski and the Polish Beginnings of 'Western Marxism'”. . Oxford: Clarendon Press.

Wyka, K. (1972). Filozofia czynu i pracy u Jerzego Sorela i Stanisława Brzozowskiego. Pamiętnik Literacki: czasopismo kwartalne poświęcone historii i krytyce literatury polskiej, 63(3), 75-109.

Publisher's Note Springer Nature remains neutral with regard to jurisdictional claims in published maps and institutional affiliations. 